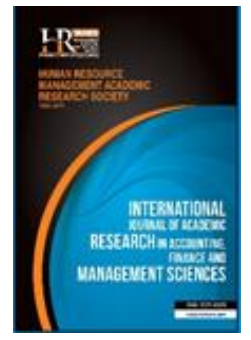

International Journal of Academic Research in Accounting, Finance and Management Sciences

Vol. 8, No.4, October 2018, pp. 131-143

E-ISSN: 2225-8329, P-ISSN: 2308-0337

(C) 2018 HRMARS

www.hrmars.com

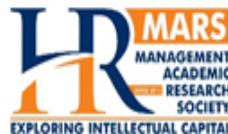

To cite this article: Umaru, H., Aguda, N.A., Davies, N.O. (2018). The Effects of Exchange Rate Volatility on Economic Growth of West African English-Speaking Countries, International Journal of Academic Research in Accounting Finance and Management Sciences 8 (4): 131-143.

\title{
The Effects of Exchange Rate Volatility on Economic Growth of West African English-Speaking Countries
}

\author{
Hussaini Umaru' ${ }^{1}$, Aguda Niyi A. ${ }^{2}$, Nordiana Osagie Davies ${ }^{3}$ \\ 1,2,3Banking and Finance Department, Waziri Umaru Federal Polytechnic, Birnin Kebbi, Kebbi State, \\ ${ }^{1}$ E-mail: umaruk002@gmail.com (Corresponding author)
}

\begin{abstract}
This paper aims to examine the effects of exchange rate volatility on economic growth of West African English speaking countries. Macroeconomic data used for this study were obtained from World Bank Data Stream between 1980 until 2017 and analyzed using Stata 14 panel data regression analysis. The results obtained showed that the independent variable (real exchange rate) is statistically significant and negatively related to the dependent variable (GDP) in West African English speaking countries excluding time-invariant variables. This current study contributes empirically regarding the relationships between exchange rate volatility and economic growth of West African English speaking countries. From 1980-2017. The findings of this study will help the countries under review and other nations in general to improve on monetary policy; it could be used by the central bank of West African English speaking countries as a guide for effective monetary policy.

Key words

Exchange rate, West Africa

Received: 12 Jan 2019 (C) The Authors 2018

Revised: 12 Feb 2019 Published by Human Resource Management Academic Research Society (www.hrmars.com)

Accepted: 19 Feb 2019 This article is published under the Creative Commons Attribution (CC BY 4.0) license. Anyone may reproduce, distribute, translate and create derivative works of this article (for both commercial and noncommercial purposes), subject to full attribution to the original publication and authors. The full terms of this license may be seen at: http://creativecommons.org/licences/by/4.0/legalcode
\end{abstract}

\section{Introduction}

The persistent fluctuations of the exchange rate have dominated recent literature in international finance owing to its effects on developing economies. Since the embracing of financial liberalization strategies, most developing countries have been exposed to sharp exchange rate fluctuations. Volatile exchange rates are related to unplanned fluctuations of relative prices in the economy. Therefore, exchange rate stability is among the major factors affecting stable economic growth, price stability and foreign (direct and portfolio) investments (Ajao and Igbekoyi, 2013). Since the era of Friedman (1953) and Humphrey (1974) exchange rate regimes are considered as the main mechanism in the analysis of economic efficiency. The effect of exchange rate volatility on growth has become a major source of concern for policymakers and researchers since the collapse of the Breton Woods treaty in 1973. The magnitude of such concern is more pronounced, especially in countries with quite low levels of financial development. In the case of African countries that in recent years have shown a sign of hope in their growth policies to transform their economies into sustainable development, the volatility of exchange-rate problem could raise into a more worrying issue in achieving their objective (Bahmani-Oskooee and Gelan, 2018). This situation has attracted the attention of professionals, previous research, and economists to focus on the effects of exchange rate volatility on growth (Barguellil et al., 2018; Soleymani and Chua, 2014). 
The relationship between exchange rate volatility and the macroeconomic performance (growth) has received considerable attention in previous studies, the outcome on the relationship between exchange rate volatility and its effect on growth has proven the existence of either a positive or negative outcome. A few studies have established that exchange rate volatility has positive effects on economic growth through the adjustment process to shocks (Barguellil et al., 2018; Edwards and Levy-Yeyati, 2005; Levy-yeyati and Sturzenegger, 2003). However, some studies have discovered the presence of negative effects of exchange rate volatility on some macroeconomic indicators that may affect economic growth such as GDP, employment, investment, international trade, and inflation (Belke and Setzer, 2003).

Exchange rate volatility can be seen as the persistent fluctuations of the exchange rate. The stability of the exchange rate in Nigeria is today formidable bedrock of all economic activities. Traditionally exchange rate played an important role in Nigeria monetary policy because of its essential impact on the inter-countries trade relation, for instance, first, being Nigeria as an import-dependent (developing) nation and second, as a mono-product (oil) export-dependent economy; besides the country's current recession and slow economic growth. Hence, the monetary authority (Central Bank of Nigeria) in recent past had engaged in so many exchange rate adjustment policies on several occasions (fixed and flexible), since the adoption of the Structural Adjustment Programme (SAP) in 1986, for the main purpose of attaining the macroeconomic objective of price stability (Ajao and Igbekoyi, 2013).

Furthermore, lack of continuity and inconsistency in policies on exchange rate policies combined with the unstable nature of the Nigerian currency (Adeniran and Yusuf, 2014). According to Omojimite and Akpokodje (2010), exchange rate volatility has been affected by structural shifts in production, institutional changes in the economy, and the changing pattern of international trade. Countries have applied monetary policies that maintain exchange rates by adopting either fixed or flexible exchange rate regimes. The adjustment from a flexible to a fixed exchange rate system has led to instabilities in exchange rates which have made researchers to examine the extent to which economic growth is affected by exchange rates volatility.

Furthermore, it's important to realize as these countries embark on achieving steady economic growth, they would likely engage in the cross-border financial transactions and liberalization of capital flows, hence, confronting increased exchange-rate movements. On the other hand, the instability of exchange-rate may instigate uncertainty among profit-maximizing traders and curtail the level of their engagement in the export and import sectors, thus leading to a diminished volume of trade and weakened economic growth (Bahmani-Oskooee and Gelan, 2018).

In spite of the obvious importance of exchange rate volatility on economic growth, few studies examined the effects of volatile exchange rate on economic growth. Though, current studies have begun to explore the effects of exchange rates on growth, through various channels such as trade, inflation, investment, unemployment, exports, and productivity, besides direct effects and causalities. For instance, in relation to exports (Alam et al., 2018; Bahmani-Oskooee and Wangr, 2015; Ekanayake and Thaver, 2011; Flavio Vilela Vieira and MacDonald, 2016), employment growth (Belke and Setzer, 2003; Chang, 2011; Mpofu, 2013; Zmami and Ben-Salha, 2015), trade and exchange rate volatility (Lin et al., 2018; Musila and Al-Zyoud, 2012; Zubair et al., 2014), inflation (Dutta and Saha, 2015; Hamid et al., 2016; Ouyang and Rajan, 2016); investment (Kumar et al., 2013; Sharifi-Renani and Mirfatah, 2012), and more generally economic activity (Adewuyi and Akpokodje, 2013; Apollos et al., 2015; Kurihara, 2013) and growth (Alagidede and Ibrahim, 2017; Flávio Vilela Vieira et al., 2013).

However, in the developing nations like West African Countries, despite the importance of exchange rate volatility on economic growth, few studies have been conducted, and most of them are not attached to the economic growth, but rather to specific sectors like import, export, FDI, and firms. For instance, (Ajao and Igbekoyi, 2013; Hassan et al., 2017; Ifeakachukwu and Ditimi, 2014; Kemisola et al., 2016; Onafowora and Owoye, 2008; Oriavwote and Oyovwi, 2012; Osigwe, 2015; Udoh and Egwaikhide, 2008) which all have certain kind of shortcomings such as small sample, limited scope, single sector, addressing issues other than economic growth, etc. In addition, considering that the major source of growth in most African countries has been a sudden increase in the volume of international trade, steered largely by the rising demand for raw materials and higher commodity prices, studying the effects of the relationship between exchange-rate volatility and economic performance is very timely and important for these countries (Bahmani-Oskooee and Gelan, 2018). Therefore this paper will look at the effects of exchange rate volatility on growth by 
comprehensively looking at macroeconomic variables such as import, export, GDP, foreign direct investment, and reserve money from 1986-2017.

In addition, lack enough research and inconclusive findings on the impact of exchange rate volatility on economic growth warrants this study to be conducted to overcome the limitation of previous studies that have overlooked the exchange rate volatility issues on economic growth specifically in African context like West African countries. This study differs from previous researches by carrying out a comprehensive analysis of the nexus between exchange rate volatility and macroeconomic variables (particularly imports, exports, inflation, and foreign direct investment). The following research question is expected to be answered by this paper: Does exchange rate volatility has any effect on economic growth (macroeconomic variables) of West African English speaking countries? Specifically, the objective of the study is to determine the effects of exchange rate volatility on economic growth (macroeconomic variables) of West African English speaking countries.

\section{Literature review}

Exchange rate refers to the currency rate of one country in terms of currency of another country (Bagh et al., 2017). Exchange rate volatility, which is generally defined as the risk associated with unpredicted movements in exchange rates, has a direct effect on a country's economic policy (Meniago and Eita, 2017). The adoption of the floating exchange rate regime in the late 1970s has brought about significant instability in exchange rates. Ever since the fall of the Bretton Woods System in the early 1970s, the effect of exchange rate volatility on economic growth has gained considerable attention from the researchers, policymakers, and other professional bodies, as it is perceived to be the backbone of the economy (Abdul-rahamoh et al., 2013). There has been inconsistency among the researcher's findings throughout the years with evidence on both negative and positive impacts of exchange rate volatility on the nation's growth.

Several empirical studies have investigated the impact of exchange rate volatility on the macroeconomic performance (economic growth) both theoretically and empirically. Other economic growth indicators include domestic investments have also been investigated (Ugwu and Udeh, 2018). Despite the immense research on the topic, there is still no general unanimity that has been reached (Meniago and Eita, 2017). The literature reveals diversified outcomes are making this topic an empirical question which still requires further investigation. While some studies revealed the existence of a negative relationship, others established a positive nexus, while others found no significant relationship at all (Meniago and Eita, 2017).

For instance, Chowdhury and Wheeler (2008) studied the relationship between the exchange rate volatility for the four developed countries of the United Kingdom, the United States, Japan, and Canada, this study applied a vector autoregressive (VAR) approach and found that exchange rate volatility has a positive and significant impact on the flow of FDI. Also, Edwards and Levy-Yeyati (2005) revealed that exchange rate volatility impacts positively on economic growth through its effect on the adjustment process to shocks. This is supported by Shafi et al. (2015) who revealed that exchange rate volatility is positively significance with growth. While, Danmola (2013) examined the effects of exchange rate volatility on the Nigerian macroeconomic variables, the findings of the study revealed that volatile exchange rate has a positive effect on FDI, GDP, and trade openness with a negative effect on the inflationary rate in the country.

In addition, Kasman and Kasman (2005) investigated the impact of volatile exchange rate on Turkey's exports using quarterly data from 1982-2001. Cointegration and error-correction modeling approaches are applied and revealed that volatile exchange rate has a positive significant effect on export volume in the long run. Furthermore, Jakob (2016) empirically revealed that there is a positive and significant correlation between the fixed exchange rate and growth in GDP. Also, Ekanayake and Thaver (2011) investigated the impact of exchange rate volatility on South Africa's trade flows over the period 1980-2009. The results of the analysis revealed the positive dependence of imports on the level of foreign exchange reserves and economic growth. Likewise, in Nigeria, Dickson, and Andrew (2013) analyzed the effect of exchange rate volatility on trade imports in Nigeria. With the aid of a standard error correction technique, the results revealed that exchange rate volatility was positively related to import/export. 
Alternatively, Other studies have rather proved the presence of a negative relationship between exchange rate volatility and some macroeconomic aggregates that may affect economic growth such as international trade, investment, and employment (Barguellil et al., 2018; Belke and Gros, 2001). For instance, the volatile exchange rate can have negative effects on economic growth through its effect on the main determinants of the economic activity, such as Trade flows, exports, Inflation, employment, imports, and FDI. Regarding these points, numerous studies have shown that volatile exchange rate often leads to a reduction in the volume of international trade (Barguellil et al., 2018; Hooper and Kohlhagen, 1978). In a study conducted by Sekkat and Varoudakis (2000) using standard econometric techniques, revealed that a significant negative effect exists between exchange rate volatility and textile and chemical exports of nonCFA countries but the insignificant positive effect on those of CFA countries. Also, Tenreyro (2007) and Arize et al. (2000) found a negative relationship between exchange rate volatility and exports in new emerging countries.

In a similar study by Khosa et al. (2015), the findings revealed that significant negative effect exists between exchange rate volatility and the performance of exports. Also, David et al. (2010) examined the effect of exchange rate fluctuations on Nigerian manufacturing industry; multiple regression econometric tools were employed, their results revealed a negative relationship between the performance of manufacturing sector and exchange rate volatility. Also, Aghion et al. (2009) found a similar result, but they also revealed that negative effects of exchange rate volatility on economic growth diminishes in countries with higher levels of financial development. Furthermore, Hall et al.(2010) compare the effects of exchange rate volatility and export performance of emerging economies with developing countries, the results of the study revealed statistically significant results with the negative relationship for developed countries but revealed no significant relationship for emerging markets. In addition, Oseni (2016) in a study carried out in Sub- Saharan African (SSA) Countries shows the existence of a negative and significant relationship between exchange rate volatility and private consumption in SSA countries.

On the other hand, some study does not find any significant effects between exchange rate volatility and growth. For instance, Asseery and Peel (1991), among others, do not find support for the impact of exchange rate volatility on trade. Also, Clark et al. (2004) revealed that the volatile exchange rate has no significant effect on trade. Similarly, Solakoglu et al. (2008) found that there were no positive or negative effects of the exchange rate instability on exports for some firms in Turkey. In addition, Hondroyiannis et al. (2008) investigated the relationship between aggregate export volumes and exchange rate volatility for twelve industrial countries; the study revealed that there is no negative/positive significant relationship between exchange rate volatility and trade.

The mixed results on the relationship between the exchange rate volatility on the macroeconomic performance (economic growth), is as a result of difference in methodology and estimation techniques; scholars could not arrive at the same conclusion. The other reason for different results is different data time spans. Therefore, this research aims to find the exchange rate volatility on the macroeconomic performance (economic growth) in Nigeria. This research applied the econometric model in investigating the effects of exchange rate volatility on the macroeconomic performance (economic growth) by using GDP as a proxy for economic growth for the period 1986-2017.

Furthermore, the mixed results can be explained at least for two reasons. First, exchange rate volatility may be related with higher macroeconomic instability in terms of economic growth, investment, international trade, and inflation, on the other hand, exchange rate volatility may be seen as a shock absorber and appears to be more applicable for countries experiencing real shocks frequently. Second, the relationship between economic growth and exchange rates also depends on other control variables such as financial development (Aghion et al., 2009; Barguellil et al., 2018).

Volatile exchange rate shatters the confidence of investors, destabilizes the capital movements, and slows down the process of trade which slows down the process of growth. Volatility refers to how exchange rate is settled on supply and demand of local currency vis-à-vis to foreign currency. Exchange rate volatility can impact affect the volume of imports, exports, reserve money, policy decisions, and disturbs the allocation of productive resources and the balance of payments. Exchange rate volatility provides chances to domestic investors to obtain higher profits, to invest in foreign currency.

There are three following views on the impact of the fluctuation of exchange rate on economic growth: the first view is that the depreciation of exchange rate has an expansionary effect on economic 
growth (Hausmann et al., 2005; Hooy et al., 2016). Through the study on the effect of economic growth with the depreciation of real exchange rate by the sample of developing countries, Rodrik (2008) found that the depreciation of the real exchange rate was beneficial to the trade department, and it is able to increase the investment returns for the trade department and reduce the cost of system and market distortions Rodrik (2008); therefore, the devaluation of the real exchange rate will increase economic growth by the expansion effect on economic growth. The second view is that the depreciation of the exchange rate has a "contractionary effect" on economic growth" (Mbaye, 2013). However, Wang, Ye, and Li (2016) believed that the depreciation of the exchange rate could lead to the contractionary effect mainly through four ways: first, reducing product supply; second, causing inflation; third, leading to foreign drain; and fourth, increasing debt burden; the third view holds that the effect of exchange rate depreciation on economic growth is uncertain (Fung, 2008).

\subsection{Related Theories}

Previous literature and theories on the effect of exchange rate volatility on economic growth is still an area that is receiving attention and debate among economist. At the theoretical level, while some studies suggest that continue fluctuations in exchange rates can affect the domestic economy negatively. For instance, Devereux et al. (2003) contend that the welfare effects of volatile exchange rate are provisional upon the way in which prices are set. The empirical literature is equally inconsistent regarding the effects of exchange rate volatility on economic growth as discussed above.

Theoretical Background: Exchange rate moves up and down due to the dynamic nature of business environment coupled with the fluctuation of other macroeconomic factors. An upward movement indicates a gain in value (appreciation) while a downward movement indicates a loss in value (depreciation) against other foreign currency Ibenta (2012) as cited in (Anyanwu et al., 2017). Theories such as real options theory, interest rate parity theory, purchasing power parity, portfolio balance model, traditional flow theory, and etc. have been developed in the previous literature to explain this up and down movement in the exchange rate. However, this paper centered on the real options theory and purchasing power parity theory.

Recently, the advance of real options theory led to better analyze the effects of macroeconomic uncertainty on economic operators' decisions (Dixit et al., 1994). Furthermore, the application of this theory in an open economy has caused researchers attention to focus on the relationship between exchange rate volatility as a factor of uncertainty and its effects on economic growth. In addition, Serven (1997) revealed that exchange rate uncertainty explains postponement and waiting behaviors in relation to investment decisions. This is supported by Belke and Gros (2001) who confirm that exchange rate volatility favors the "wait-and-see strategy." When making a hiring decision, companies also incur additional costs, such as costs of providing capital to a particular job and hiring costs. Therefore, an increase in exchange rate volatility may discourage firms from increasing investment and creating jobs (Belke and Setzer 2003).

\subsection{Purchasing Power Parity Theory}

The purchasing power parity (PPP) relationship is a relevant concept under flexible and fixed exchange rates system; it has been used as an explanation of inflation and of movements in a freely floating exchange rate. Most recently, the absolute explanation of the purchasing-power parity doctrine has been raised by Balassa (1964) who have expressed the opinion that the relative price levels of consumer goods provide an indication of the over or undervaluation of individual currencies (Genberg, 1978). In an effort to retort to call for a substitute exchange rate determination system following the fall of the fixed exchange rate system, the purchasing power parity theory was advanced.

The theory states that the exchange rate between two currencies is solely determined by the movement of demand and supply forces. The foundation of the theory is that, if any pair of currency is set at par, then, the exchange rate differential should reflect variations arising from the purchasing powers of the relative currency in relation to the Base Exchange rates (Anyanwu et al., 2017). The purchasing power parity theory has undergone reforms over time and general acceptance by international financial market operators in determining the exchange rate between two currencies (Anyanwu et al., 2017) 
The traditionalist view on the influence of currency depreciation on trade indicates that it leads to an expansion of trade via an increase in imports prices and lower export prices. The structuralist school, however, opposed some expansionary effects, (Umaru et al., 2013). Hirschman (1943) revealed that depreciation of currency from an initial trade deficit reduces real national income and may result in a fall in aggregate demand. However, Kandil and Mirzaie (2002) maintained that depreciation of currency gives with one hand, by reducing export prices and increase imports prices. They observed that If imports exceed exports, these price changes offset each other in terms of trade remain unchanged and the trade is in balance, especially when the famous Marshall-Lerner condition is not satisfied (Umaru et al., 2013).

However, previous literature on the exchange rate system and the theory of economic growth revealed that the exchange rate system choice could have an influence on economic growth over the medium term. These effects can arise either indirectly through the main determinants of economic growth such as financial development, trade, and investment or directly from the effects of shock adjustments (Haj fraj et al., 2018).

Conclusively, the effect of exchange rate volatility on the economic growth of a country or a region is unstable and complex. This is because exchange rate volatility does not directly affect the economic growth itself, but affects the factors that are influence the macroeconomic growth to indirectly affect the economic growth. Though the constituting factors of economic growth are many, and the affected relationship by the exchange rate are mixed, therefore impact of changes in the exchange rate on economic growth needs the in-depth analysis of various factors of economic growth to reveal changes in the exchange rate, so as to systemically determine the precise effects for the fluctuations of exchange rate (Wang et al., 2016).

\section{Methodology of research}

Economic growth is determined by various macroeconomic indices which include but not limited to GDP, export, import, exchange rate, and inflation. This study depends on annual time series data taken from World Bank Data Stream for four English speaking countries of West Africa (Ghana, Gambia, Nigeria, and Sierra Leone), though Liberia is part of the English speaking country in the region, but it was removed due to unavailability of data on the variables under study. The data collected; GDP per capita as the dependent variable and real exchange rate as an independent variable. This cross-sectional research will be examining the relationship between the exchange rate and GDP growth across English speaking of West African countries for the period between $1980-2017$.

This study applied three types of panel data namely; Pooled OLS model, Fixed Effect Model, and Random Effect Model are used to analyze the data. All coefficient and intercept are assumed to be fixed in the constant coefficient model. Hence, space and time variant are overlooked.

\subsection{Pooled Ordinary Least Square}

To prove the reliability of our samples, we first estimate our equation as follows:-

$\mathrm{GDP}=\beta_{0}+\beta_{1} \mathrm{REX}+\mu \mathrm{t}$

Where:

GDP = Gross Domestic Product;

RER = Real Exchange Rate;

$\mu \mathrm{t}=$ Error Terms of the Mode.

Pooled OLS model estimate the model by ignoring the panel structure of the data. Pooled OLS is used to test whether Pooled OLS or panel data can estimate the data set (Aparaschivei, 2012).

$\mathrm{Y}=\beta_{0}+\beta_{1} X_{1 i t}+\beta_{2} X_{2 i t}+\cdots+\varepsilon_{i t}$

Where:

$\varepsilon_{i t}=\lambda_{i}+u_{i t}$

$u_{i t} \sim N\left(0, \sigma_{u}^{2}\right)$

The $u_{i t}$ is called the time-varying error. Its use is to describe variations over time and among the components in panel data. On the other hand, $\lambda_{\mathrm{i}}$ is unobserved heterogeneity. 


\subsection{Fixed Effects Model}

The fixed effect also is known as the unobserved effect. In the fixed-effect analysis, all studies are assumed to have the same true side effect. The summary effect will be our estimate of this common effect size. As it relies on the variation that occurs within individuals rather than between individuals, it is called the "within" estimator. The assumption in fixed effect model assumes $\lambda_{i}$ are constant.

$$
\mathrm{Y}=\left(\beta_{0}+\lambda_{i}\right)+\beta_{1} X_{1 i t}+\beta_{2} X_{2 i t}+\cdots+u_{i t}
$$

Fixed-effects (FE) can be used whenever the researcher is only interested in analyzing the impact of variables that vary over time. FE explores the relationship between predictor and outcome variables within an entity (country, person, company, etc.). for instance, each entity has its own individual characteristics that may or may not influence the predictor variables (for example, the business practices of a company may influence its stock price; or political system of a particular country could have some effect on trade or GDP).

Hence the fixed effects model for some variable $y_{i t}$ may be re-written;

$$
y_{i t}=\alpha+\beta x_{i t}+\mu+v_{\text {it }}
$$

We can think of $\mu$ i as summarizing all of the variables that affect $y_{\text {it }}$ cross-sectionally but do not vary over time - for example, the sector that a firm operates in, a person's gender, or the country where a bank has its headquarters, etc. Thus we would capture the heterogeneity that is encapsulated in $\mu \mathrm{i}$ by a method that allows for different intercepts for each cross-sectional unit.

\subsection{Random Effects Model}

An alternative to the fixed effects model described above is the random effects model, which is sometimes also known as the error components model. In the random-effects analysis, the assumption is that the true effect size is different from one time to another and in our analysis represents a random sample of effect sizes that could have been observed. The summary effect will be our estimate of the mean of these effects. Random effect assumes $\lambda_{i}$ are drawn from the different probability distribution. The random effect has the following form:

$$
\mathrm{Y}=\beta_{0}+\beta_{1} X_{1 i t}+\beta_{2} X_{2 i t}+\cdots+\lambda_{i}+u_{i t}
$$

The random effects approach proposes different intercept terms for each entity, and again these intercepts are constant over time, with the relationships between the explanatory and explained variables assumed to be the same both cross-sectionally and temporally. However, the difference is that under the random effects model, the intercepts for each cross-sectional unit are assumed to arise from a common intercept $\alpha$ (which is the same for all cross-sectional units and over time), plus a random variable $\lambda i$ that varies cross-sectionally but is constant over time. Hence the fixed effects model for some variable it may be re-written;

$$
y_{\text {it }}=\alpha+\beta x_{\text {it }}+\lambda_{\text {it }} \text { where, } \quad \lambda_{\text {it }=\varepsilon_{\text {it }} v_{\text {it }}}
$$

\subsection{Hausman Test}

Hausman test has been used in this project. To decide between the fixed effect or random effect model, this study ran the Hausman test. It is a general test that assesses the uniformity of an estimator when compared to an alternative. It helps one identify if a statistical model correlates to the data. The Hausman specification test model would be as follow:

$$
\mathrm{H}=\left(\hat{\beta}_{r e}-\hat{\beta}_{f \varepsilon}\right)^{\prime}\left(\operatorname{Var}\left(\hat{\beta}_{f \theta}\right)-\operatorname{Var}\left(\hat{\beta}_{r \varepsilon}\right)\right)^{-1}\left(\hat{\beta}_{r e}-\hat{\beta}_{f e}\right)
$$

If the null hypothesis shows that $\hat{\beta}_{r e}$ is inconsistent and we should apply the fixed effect model in the study.

\subsection{Data Analysis}


This part will include results and explanation of fixed effect and random effect. Some specification test conducted by using some test like Hausman test, Breusch, and Pagan Lagrangian multiplier test and Ftest. The test aims to find the best model for this study.

Table 1. Descriptive statistics

\begin{tabular}{cccccc}
\hline Variable & Obs. & Mean & Std. Dev. & Min & Max \\
\hline GDP & 152 & 3.5101 & 6.1456 & -20.5990 & 33.7360 \\
RER & 152 & 2.1672 & 0.2850 & 1.6900 & 3.5370 \\
\hline
\end{tabular}

Note: $G D P=G D P$, and $R E R=$ Real Exchange rate.

Table 1 above shows descriptive statistics which shows the total observation (Obs), mean, variables, minimum, and maximum values of each variable used in this study. The results show that GDP has an average of 3.5101 with a standard deviation of $6.15 \%$. The results revealed that the mean value for real exchange rate (RER) is 2.1672 , which means real exchange rate is highly related GDP, with a standard deviation of $28 \%$, with minimum and the maximum value of 1.6900 and 3.5370 respectively.

Table 2. OLS, FE, and RE

\begin{tabular}{lcccccc}
\hline \multicolumn{1}{c}{ Variables } & \multicolumn{2}{c}{ Pooled OLS } & \multicolumn{2}{c}{ FE } & \multicolumn{2}{c}{ RE } \\
\hline \multicolumn{1}{c}{ GDP } & Coef. & $\mathbf{P}>|\mathbf{t}|$ & Coef. & $\mathbf{P}>|\mathbf{t}|$ & Coef. & $\mathbf{P}>|\mathbf{t}|$ \\
\hline Cons & 16.4337 & 0.000 & 17.0282 & 0.000 & 16.4337 & 0.000 \\
RER & -5.98112 & 0.000 & -62563 & 0.000 & -5.9812 & 0.000 \\
\hline Hausman & $\mathbf{C h i}^{2}=\mathbf{1 . 1 6}$ & & & $\mathbf{P}=\mathbf{0 . 2 8 1}$ & & \\
Wald statistic for GroupWise & $\mathrm{Chi}^{2}=\mathbf{2 1 8 . 8 2}$ & & & $\mathbf{P}=\mathbf{0 . 0 0 0}$ & & \\
\hline
\end{tabular}

Note: $G D P=G D P$ Per capita, RER=Real exchange rate,

Table 2: above shows the Wald test has shown that Heteroskedasticity does not exist for the study. Although the result of the Hausman test the prob. $>5 \%$ supported the alternative hypothesis fixed effect (FE) by having a p-value of more than 0.05 on Hausman test. The study also reports both Pooled OLS (ordinary least square) and random effect model (RE) to look at the relationship in the model.

\subsection{Regression Results}

Table 2 above shows the OLS result coefficient for RER is -5.9811 with a negative significant relationship with the GDP. The results reveal that there is a negative relationship between the real exchange rate and gross domestic product (GDP). Indicating that an increase in the real exchange rate of $1 \%$ will lead to the decrease in GDP by $5.98 \%$. According to Hausman test fixed effect model is the most suitable model for this study. The Fixed Effect $(F E) R^{2}$ within is 0.0833 . This shows that the model explains $8.33 \%$ of changes in GDP. The model statistically negatively significant at $1 \%$ level.

This study has three alternative models (i.e., OLS, FE, and RE) to estimate GDP and RER in 4 English speaking countries of West Africa. The Hausman test results support FE against Pooled OLS and RE. And therefore report FE to be more suitable for this study. See table 2 for details.

\subsection{The implication of the study to ASEA 5}

The findings show the variable is significant, RER is statistically significant and has a negative relationship with GDP, this relationship indicates that the GDP reduce as a result of an increase in exchange rate volatility which is consistent with (Barguellil et al., 2018; Belke and Gros, 2001). The implication of these findings is GDP is a negative response to RER four English speaking West African countries. The above finding indicates that a relationship exists for all the four English speaking countries of West Africa between the dependent variable and independents variables at $1 \%$.

Table 3. Regression analysis for cross-sectional data

\begin{tabular}{lcccc}
\hline & Cons & RER & $\mathbf{R}^{2}$ & Country \\
\hline Coef. & 1.475 & 0.9176 & & \\
$\mathbf{T}$ & 0.240 & 0.330 & 0.003 & Gambia \\
\hline
\end{tabular}




\begin{tabular}{lcccc}
\hline & Cons & RER & $\mathbf{R}^{2}$ & Country \\
\hline $\mathbf{P}>|\mathbf{t}|$ & 0.810 & 0.744 & & \\
Coef. & 18.724 & -6.396 & & \\
$\mathbf{T}$ & 8.030 & -6.160 & 0.513 & Ghana \\
$\mathbf{P}>|\mathbf{t}|$ & 0.000 & $0.000^{*}$ & & \\
Coef. & 22.646 & -9.184 & & \\
$\mathbf{T}$ & 2.55 & -2.18 & 0.117 & Nigeria \\
$\mathbf{P}>|\mathbf{t}|$ & 0.015 & $0.036^{* *}$ & & \\
Coef. & 15.544 & -6.014 & & \\
$\mathbf{T}$ & 1.08 & -0.91 & 0.022 & Sierra Leone \\
$\mathbf{P}>|\mathbf{t}|$ & 0.289 & 0.370 & & \\
\hline
\end{tabular}

Note: GDP = GDP per capita for a country, RER= Real exchange rate, *Significant at 0.01 level ${ }^{*}$ Significant at 0.05 level

Table 3 above shows a regression analysis of cross-sectional data for four English speaking countries of West Africa.

The regression results for the country Gambia reveals that there is no statistical relationship between real exchange rate and GDP with P-value of 0.744 . The explanatory power between GDP and RER provides only $0.3 \%$. In essence, the regression results for the Gambia provide an insignificant relationship with the GDP. In Ghana, the variable RER (Coef. $=-6.396$, at a significant level of $1 \%, p=0.000$ ) is negatively related to GDP with the explanatory power of $51.28 \%$. The implication of the results is that an increase in the exchange rate with $1 \%$ will lead to a decrease in GDP by $6.34 \%$.

In Nigeria also negative relationship exists between RER and GDP with Coef. $=-9.184$ and P-values= 0.036 showing significant at $5 \%$. This indicates that an increase in $5 \%$ of the exchange rate will lead to a decrease in GDP by $9.184 \%$ with the explanatory power of $11.68 \%$. The regression results for the country Sierra Leone revealed an insignificant result, meaning there is no relationship between exchange rate and GDP of Sierra Leone. With coef. $=-6.014$, $p$-value $=0.370$ with the explanatory power of only $2 \%$. In general, table 3 above shows a regression analysis of cross-sectional data for four English speaking of West African countries. RER reported a negative statistical significant relation at $1 \%$ level from Ghana and Nigeria at 5\% and insignificant relationship at Gambia and Sierra Leone with GDP. A negative and significant relationship is found in Ghana and Nigeria between RER and GDP while Gambia and Sierra Leone present insignificant results.

\section{Conclusions}

This study aims at contributing to the current and intense debate among economists the effects of exchange rate volatility and economic growth by examining the effects of exchange rate volatility on economic growth of English speaking country of West Africa. The results of the study revealed that there is a significant negative relationship between exchange rate volatility and economic growth on the four English speaking country of West Africa (Nigeria, Ghana, Gambia, and Sierra Leone (see table2). However, individually the finding revealed that the effect of exchange rate volatility on economic growth is statistically significant in Ghana and Nigeria with a negative relationship on economic growth of these countries. However an insignificant result is also reported on Gambia and Sierra Leone. These results have important implications for the design of exchange rate policies in the English speaking country of West Africa. Given the importance of exchange rate on economic growth through facilitating international trade and investment in the country, these countries' monetary authorities, government and other relevant agencies should adopt measures that will discourage imports and encourage exports and adapt an exchange rate policy that principally seeks to stabilize exchange rates. A predictable and relatively stable exchange rate seems to be essential in enhancing economic growth. The study has some limitations which include measuring growth with single proxy (GDP) only; other researchers should consider using multiple variables that explain the growth in an economy. Also, the study focused on English speaking country of West Africa only; future researchers should add the scope to cover the African continent. 


\section{References}

1. Abdul-rahamoh, O. a, Taiwo, F. H., \& Adejare, A. T. (2013). The analysis of the effect of petroleum profit tax on Nigerian economy. Asian Journal of Humanities and Social Sciences (AJHSS), 1(1), 25-36.

2. Adeniran, J. O., \& Yusuf, S. A. (2014). The Impact of Exchange Rate Fluctuation on the Nigerian Economic Growth: An Empirical Investigation. International Journal of Academic Research in Business and Social Sciences, 4(8), 2222-6990. https://doi.org/10.6007/IJARBSS

3. Adewuyi, A. O., \& Akpokodje, G. (2013). Exchange Rate Volatility and Economic Activities of Africa's Sub-Groups. International Trade Journal, 27(4), 349-384. https://doi.org/10.1080/ 08853908. 2013.813352

4. Aghion, P., Bacchetta, P., Rancière, R., \& Rogoff, K. (2009). Exchange rate volatility and productivity growth: The role of financial development. Journal of Monetary Economics, 56(4), 494-513. https://doi.org/10.1016/j.jmoneco.2009.03.015

5. Ajao, M. G., \& Igbekoyi, E. O. (2013). The Determinants of Real Exchange Rate Volatility in Nigeria. Academic Journal of Interdisciplinary Studies, 2(1), 459-471. https://doi.org/10.5901/ajis/2013.2n1p459

6. Alagidede, P., \& Ibrahim, M. (2017). On the Causes and Effects of Exchange Rate Volatility on Economic Growth: Evidence from Ghana. Journal of African Business, 18(2), 169-193. https://doi.org/ 10.1080/15228916.2017.1247330

7. Alam, S., Ahmed, Q. M., \& Shahbaz, M. (2018). The Effect of Exchange Rate Volatility on Pakistan's Bilateral Exports to Major Recipients. Global Business Review, 19(2), 328-341. https://doi.org/10.1177/ 0972150917713539

8. Anyanwu, F. A., Ananwude, A. C., \& Okoye, N. T. (2017). Exchange Rate Policy and Nigeria's Economic Growth: A Granger Causality Impact Assessment. International Journal of Applied Economics, Finance and Accounting, 1(1), 1-13.

9. Aparaschivei, L. (2012). Analysis of the Romanian employment rate. A panel data approach. Theoretical and Applied Economics, XIX(7), 13-24.

10.Apollos, E. A., Emmanuel, A., \& Olusegun, D. J. (2015). Exchange Rate Volatility and Economic Growth in Nigeria (1986-2013). Journal of Empirical Economics, 4(2), 109-115.

11.Arize, A. C., Osang, T., \& Slottje, D. J. (2000). Exchange-rate volatility and foreign trade: Evidence from thirteen LDC's. Journal of Business and Economic Statistics, 18(1), 10-17. https://doi.org/10.1080/ 07350015.2000.10524843

12.Asseery, A., \& Peel, D. A. (1991). The effects of exchange rate volatility on exports. Economics Letters, 37(2), 173-177. https://doi.org/10.1016/0165-1765(91)90127-7

13.Bagh, T., Azad, T., Razzaq, S., Liaqat, I., \& Khan, M. A. (2017). The Impact of Exchange Rate Volatility on Stock Index: Evidence from Pakistan Stock Exchange (PSX). International Journal of Academic Research in Accounting, Finance and Management Sciences, 7(3), 70-86. https://doi.org/10.6007/ IJARAFMS/v7-i3/3150

14.Bahmani-Oskooee, M., \& Gelan, A. (2018). Exchange-rate volatility and international trade performance: Evidence from 12 African countries. Economic Analysis and Policy, 58, 14-21. https://doi.org/10.1016/j.eap.2017.12.005

15.Bahmani-Oskooee, M., \& Wangr, Y. (2015). The Impact of Exchange Rate Volatility on Commoditv Trade between the U.S. and China. Economic Issues, 12(1), 2-7.

16.Balassa, B. (1964). The Purchasing-Power Parity Doctrine: A Reappraisal. Journal of Political Economy, 72(6), 584-596.

17.Barguellil, A., Ben-Salha, O., \& Zmami, M. (2018). Exchange rate volatility and economic growth. Journal of Economic Integration, 33(2), 1302-1336.

18.Belke, A., \& Gros, D. (2001). Real impacts of Intra-European exchange rate variability: A case for EMU? Open Economies Review, 12(3), 231-264. https://doi.org/10.1023/A:1011112105352

19.Belke, A., \& Setzer, R. (2003). Exchange Rate Volatility and Employment Growth: Empirical Evidence from the CEE Economies (No. 1056). Munich.

20.Chang, S.-C. (2011). The interrelationship between exchange-rate uncertainty and unemployment for South Korea and Taiwan: Evidence from a vector autoregressive approach. International Economics, 125, 65-82. https://doi.org/10.1016/\$2110-7017(13)60025-6 
21.Chowdhury, A. R., \& Wheeler, M. (2008). Does real exchange rate volatility affect foreign direct investment? Evidence from four developed economies. International Trade Journal, 22(2), 218-245. https://doi.org/10.1080/08853900801970601

22.Clark, P. B., Tamirisa, N., Wei, S.-J., Sadikov, A., \& Zeng, L. (2004). A new look at exchange rate volatility and trade flows. International Monetary Fund, (235).

23.Danmola, R. A. (2013). The Impact of Exchange Rate Volatility on the Macroeconomic Variables in Nigeria. European Scientific Journal, 9(7), 152-165. Retrieved from http://eujournal.org/index.php/esj/ article/view/861

24.David, O., Umeh, J. C., \& Ameh, A. A. (2010). The effect of exchange rate fluctuations on the Nigerian manufacturing sector. African Journal of Business Management, 4(14), 2994-2998. https://doi.org/10.3968/j.ibm.1923842820120402.1075

25.Devereux, M. B. ., Engel, C., \& Tille, C. (2003). Exchange Rate Pass-through and the Welfare Effects of the Euro. International Economic Review, 44(1), 223-242.

26. Dickson, O. O., \& Andrew, U. (2013). Exchange Rate Volatility Effect on Trade Variations in Nigeria. Mediterranean Journal of Social Sciences, 4(6), 401-406. https://doi.org/10.5901/mjss.2013.v4n6p401

27.Dixit, A. K., Dixit, R. K., Pindyck, R. S., \& Pindyck, R. (1994). Investment under uncertainty. New Jersey, USA: Princeton university press,.

28.Dutta, K. D., \& Saha, M. (2015). Interaction of Inflation, Interest Rate and Remittance with Exchange Rate in Bangladesh. NU Journal of Humanities, Social Sciences \& Business Studies, 1(2).

29.Edwards, S., \& Levy-Yeyati, E. (2005). Flexible exchange rates as shock absorbers. European Economic Review, 49(8), 2079-2105. https://doi.org/10.1016/j.euroecorev.2004.07.002

30.Ekanayake, E. M., \& Thaver, R. (2011). The Impact of Dollar-Rand Volatility on U.S. Exports to South Africa. The International Journal of Business and Finance Research, 5(3), 73-85. https://doi.org/http://www.theibfr.com/ijbfrsample.htm

31. Friedman, M. (1953). The case for flexible exchange rates.

32.Fung, L. (2008). Large real exchange rate movements, firm dynamics, and productivity growth. Large Real Exchange Rate Movement, 41(2), 391-424.

33.Genberg, H. (1978). Purchasing power parity under fixed and flexible exchange rates. Journal of International Economics, 8(2), 247-276. https://doi.org/10.1016/0022-1996(78)90023-5

34. Haj fraj, S., Hamdaoui, M., \& Maktouf, S. (2018). Does Regime Choice Affect Exchange Rate Volatility-Economic Growth Link? An Application of Panel-VAR Approach. International Economic Journal, 32(1), 1-30. https://doi.org/10.1080/10168737.2018.1423627

35.Hall, S., Hondroyiannis, G., Swamy, P. A. V. B., Tavlas, G., \& Ulan, M. (2010). Exchange-rate volatility and export performance: Do emerging market economies resemble industrial countries or other developing countries? Economic Modelling, 27(6), 1514-1521. https://doi.org/10.1016/j.econmod. 2010.01.014

36. Hamid, M., Shahzad, A., Saqib, M. H., \& Maqbool, B. (2016). Impact of inflation, interest rate and GDP on the Exchange rate volatility in Pakistan. International Journal of Research in Management and Business, 2(4), 65-72.

37. Hassan, A., Abubakar, M., \& Dantama, Y. U. (2017). Determinants of Exchange Rate Volatility: New Estimates from Nigeria. Eastern Journal of Economics and Finance, 3(1), 1-12. https://doi.org/10.20448/ 809.3.1.1.12

38. Hausmann, R., Pritchett, L., \& Rodrik, D. (2005). Growth accelerations. Journal of Economic Growth, 10(4), 303-329. https://doi.org/10.1007/s10887-005-4712-0

39. Hirschman, A. O. (1949). Professor Schumpeter's Theory of Innovation. The Review of Economics and Statistics, 25(1), 93-96. https://doi.org/10.1111/j.I

40. Hondroyiannis, G., Swamy, P. A. V. B., Tavlas, G., \& Ulan, M. (2008). Some further evidence on exchange-rate volatility and exports. Review of World Economics, 144(1), 151-180. https://doi.org/ 10.1007/s10290-008-0141-4

41.Hooper, P., \& Kohlhagen, S. W. (1978). The effect of exchange rate uncertainty on the prices and volume of international trade. Journal of International Economics, 8(4), 483-511. https://doi.org/10.1016/0022-1996(87)90001-8 
42.Hooy, C. W., Baharumshah, A. Z., \& Brooks, R. D. (2016). The Effect of Exchange Rate Volatility on the Nexus of Technology Sophistication and Trade Fragmentation of ASEAN5 Exports to China. Journal of Asia-Pacific Business, 17(3), 206-228. https://doi.org/10.1080/10599231.2016.1203717

43. Humphrey, T. M. (1974). The Quantity Theory of Money : its Historical Evolution and Role in Policy Debates. Economic Review.

44.Ifeakachukwu, N. P., \& Ditimi, A. (2014). Capital Inflows and Exchange Rate in Nigeria. Mediterranean Journal of Social Sciences, 5(7), 263-272. https://doi.org/10.5901/mjss.2014.v5n7p263

45.Jakob, B. (2016). Impact of Exchange Rate Regimes on Economic Growth. Undergraduate Economic Review, 12(1).

46.Kandil, M., \& Mirzaie, A. (2002). Exchange rate fluctuations and disaggregated economic activity in the US: Theory and evidence. Journal of International Money and Finance, 21(1), 1-31. https://doi.org/10.1016/S0261-5606(01)00016-X

47.Kasman, A., \& Kasman, S. (2005). Exchange rate uncertainty in Turkey and its impact on export volume. METU Studies in Development, 32, 41-58.

48. Kemisola, O. C., Ademola, O. J., Olamide, J. O., \& Moses, O. I. (2016). Exchange Rate Volatility and Banks Performance : Evidence from Nigeria. International Journal of Economics and Business Management, 2(4), 1-11.

49.Khosa, J., Botha, I., \& Pretorius, M. (2015). The impact of exchange rate volatility on emerging market exports. Acta Commercii, 15(1), 1-11. https://doi.org/10.4102/ac.v15i1.257

50.Kumar, S., Chowdhury, M. B., \& Rao, B. B. (2013). Demand for money in the selected OECD countries: a time series panel data approach and structural breaks. Applied Economics, 45(14), 1767-1776. https://doi.org/10.1080/00036846.2011.637897

51.Kurihara, Y. (2013). Effects of Exchange Rate Fluctuations and Financial Development on International Trade: Recent Experience. International Journal of Business Management \& ..., 4(5), 793-801. Retrieved from http://ijbmer.com/docs/volumes/vol4issue5/ijbmer2013040504.pdf

52.Levy-yeyati, B. E., \& Sturzenegger, F. (2003). To Float or to Fix: Evidence on the Impact of Exchange Rate Regimes on Growth. American Economic Association, 96(4), 1173-1193.

53.Lin, S., Shi, K., \& Ye, H. (2018). Exchange rate volatility and trade: The role of credit constraints. Review of Economic Dynamics, 30(April), 203-222. https://doi.org/10.1016/j.red.2018.05.002

54.Mbaye, S. (2013). Currency undervaluation and growth: Is there a productivity channel? International Economics, 133, 8-28. https://doi.org/10.1016/j.inteco.2013.04.004

55.Meniago, C., \& Eita, J. H. (2017). Does Exchange Rate Volatility Deter Trade in Sub-Saharan Africa? International Journal of Economics and Financial Issues, 7(4), 62-69.

56.Mpofu, T. R. (2013). Real Exchange Rate Volatility and Employment Growth in South Africa: The Case of Manufacturing. ECCE-USB Conference, 1-34.

57.Musila, J., \& Al-Zyoud, H. (2012). Exchange Rate Volatility and International Trade Flows in subSaharan Africa: Empirical Evidence. Journal of African Business, 13(2), 115-122. https://doi.org/10.1080/ 15228916.2012.693440

58.Omojimite, B. U., \& Akpokodje, G. (2010). The Impact of Exchange Rate Reforms on Trade Performance in Nigeria. Journal of Scocial Sciences, 23(1), 53-62. https://doi.org/10.9790/59330703010715

59. Onafowora, O. A., \& Owoye, O. (2008). Exchange rate volatility and export growth in Nigeria. Applied Economics, 4O(12), 1547-1556. https://doi.org/10.1080/00036840600827676

60. Oriavwote, V. E., \& Oyovwi, D. O. (2012). The Determinants of Real Exchange Rate in Nigeria. International Journal of Economics and Finance, 4(8). https://doi.org/10.5539/ijef.v4n8p150

61.Oseni, I. O. (2016). Exchange rate volatility and private consumption in Sub-Saharan African countries: A system-GMM dynamic panel analysis. Future Business Journal, 2(2), 103-115. https://doi.org/ 10.1016/j.fbj.2016.05.004

62. Osigwe, A. C. (2015). Exchange Rate Fluctuations, Oil Prices and Economic Performance: Empirical Evidence from Nigeria. International Journal of Energy Economics and Policy, 5(2), 502-506.

63.Ouyang, A. Y., \& Rajan, R. S. (2016). Does Inflation Targeting in Asia Reduce Exchange Rate Volatility? International Economic Journal, 30(2), 294-311. https://doi.org/10.1080/10168737. 2016.1148431 
64.Rodrik, D. (2008). The Real Exchange Rate and Economic Growth. Brookings Papers on Economic Activity, (fall, 2008), 365-412. https://doi.org/10.1007/s13398-014-0173-7.2

65.Sekkat, K., \& Varoudakis, A. (2000). Exchange rate management and manufactured exports in SubSaharan Africa. Journal of Development Economics, 61(1), 237-253. https://doi.org/10.1016/S03043878(99)00067-X

66.Serven, L. (1997). Irreversibility, uncertainty and private investment: Analytical issues and some lessons for Africa. Journal of African Economies, 6(3), 229-268.

67.Shafi, K., Hua, L., Idrees, Z., Satti, J. A., \& Nazeer, A. (2015). Exchange Rate Volatility and Oil Prices Shocks. International Journal of Academic Research in Business and Social Sciences, 5(1), 249-256. https://doi.org/10.6007/IJARBSS/v5-i1/1424

68.Sharifi-Renani, H., \& Mirfatah, M. (2012). The Impact of Exchange Rate Volatility on Foreign Direct Investment in Iran. Procedia Economics and Finance, 1(September 2012), 365-373. https://doi.org/10.1016/S2212-5671(12)00042-1

69.Solakoglu, M. N., Solakoglu, E. G., \& Demirağ, T. (2008). Exchange rate volatility and exports: a firm-level analysis. Applied Economics, 40(7), 921-929. https://doi.org/10.1080/00036840600749888

70.Soleymani, A., \& Chua, S. Y. (2014). Effect of exchange rate volatility on industry trade flows between Malaysia and China. Journal of International Trade and Economic Development, 23(5), 626-655. https://doi.org/10.1080/09638199.2013.803146

71.Tenreyro, S. (2007). On the trade impact of nominal exchange rate volatility. Journal of Development Economics, 82(2), 485-508. https://doi.org/10.1016/j.jdeveco.2006.03.007

72.Udoh, E., \& Festus O. Egwaikhide. (2008). Exchange Rate Volatility, Inflation Uncertainty and Foreign Direct Investment in Nigeria. Botswana Journal of Economics, 5(2), 14-31. https://doi.org/10.4314/ boje.v5i7.60304

73.Ugwu, J. I., \& Udeh, S. N. (2018). Influence of Foreign Direct Investment on Exchange Rate and Domestic Investment in Pre- and Post- IFRS Adoption Periods of Selected Sub- Saharan African Countries ( 1999-2015 ). International Journal of Academic Research in Accounting, Finance and Management Science, 8(3), 1-16. https://doi.org/10.6007/IJARAFMS/v8-i3/4447

74.Umaru, A., Sa'idu, B. M., \& Musa, S. (2013). An Empirical Analysis of Exchange Rate Volatility on Export Trade Depertment of Agric Economics, Corresponding Author: Aminu Umaru. Journel of Emerging Trends in Economics and Management Sciences, 4(1), 42-53.

75.Vieira, F. V., Holland, M., Da Silva, C. G., \& Bottecchia, L. C. (2013). Growth and Exchange Rate Volatility : A Panel Data Analysis. Applied Economics, 45(26), 3733-3741.

76.Vieira, F. V., \& MacDonald, R. (2016). Exchange rate volatility and exports: a panel data analysis. Journal of Economic Studies, 43(2), 203-221. https://doi.org/10.1108/JES-05-2014-0083

77.Wang, S., Ye, S., \& Li, X. (2016). The Impact of Real Effective Exchange Rate Volatility on Economic Growth in the Process of Renminbi Internationalization An Empirical Study Based on VAR Model. In 4th International Conference on (pp. 1-7). IEEE.

78.Zmami, M., \& Ben-Salha, O. (2015). Exchange rate movements and manufacturing employment in Tunisia: Do different categories of firms react similarly? Economic Change and Restructuring, 48(2), 137167. https://doi.org/10.1007/s10644-015-9158-6

79.Zubair, M., Burney, I. A., Sarwat, S., \& Mubin, M. (2014). Macroeconomics Relations between Exchange Rate Instability, Exchange Rate Volatility, Trade and Economic Growth Variables: The Case of Pakistan. Journal of Economics and Sustainable Development, 5(13), 44-54. 